\title{
Yield Response of Direct Seeded Aus Rice Varieties under Rainfed Condition
}

\author{
Uttam Kumar Ghosh*, Md. Arifur Rahman Khan, M Abdul Karim, Md Anamul Haque \\ Department of Agronomy, Bangabandhu Sheikh Mujibur Rahman Agricultural University, Gazipur, Bangladesh \\ Email: *ujjal.bsmrau@gmail.com
}

How to cite this paper: Ghosh, U.K., Khan, M.A.R., Karim, M.A. and Haque, M.A. (2018) Yield Response of Direct Seeded Aus Rice Varieties under Rainfed Condition. American Journal of Plant Sciences, 9, 416-434.

https://doi.org/10.4236/ajps.2018.93032

Received: January 3, 2018

Accepted: February 11, 2018

Published: February 14, 2018

Copyright (c) 2018 by authors and Scientific Research Publishing Inc. This work is licensed under the Creative Commons Attribution International License (CC BY 4.0).

http://creativecommons.org/licenses/by/4.0/

\begin{abstract}
Rainfed Aus rice is a popular conventional rice cultivation technique that through appropriate variety selection can accelerate the benefits of the farmer. On this context, an experiment was carried out at the research field of Bangabandhu Sheikh Mujibur Rahman Agricultural University, Gazipur1706 from April to August in 2014 to evaluate yield performance of some Aus rice varieties under rainfed condition. The experiment was laid out in a split plot design with three replications. The experiment consisted of two sets of treatments: water regime as irrigated (irrigation when necessary) and rainfed (dependent on rainfall) in the main plot and 15 varieties into sub-plots. It was revealed that yield and yield contributing characters were significantly influenced by water regime, variety and their interaction. The traits like number of effective tillers and non-effective tillers.hill ${ }^{-1}$, number of filled grains and unfilled grains panicle ${ }^{-1}$, panicle length, test weight, grain yield and harvest index were higher in irrigated crops compared to rainfed. Considering the performance of yield, the highest grain yield recorded in BRRI dhan 27 (irrigated-2.47 t. $\mathrm{ha}^{-1}$ and rainfed-2.26 th ha ${ }^{-1}$ ) followed by BRRI dhan55 (irrigated-1.95 th ha ${ }^{-1}$ and rainfed-1.88 th $\mathrm{ha}^{-1}$ ), BRRI dhan 48 and BRRI dhan 43 under both irrigated and rainfed treatment. BRRI dhan 27 ranked the top under both irrigated and rainfed conditions, however the relative yield was maximum in BRRI dhan55 (reduction was only 3.59\%) followed by Nerica10. Hence, considering the yield stability and absolute yield performance, BRRI dhan 27 may be considered favorably cultivable for Aus season in Bangladesh followed by BRRI dhan55, BRRI dhan 48 and BRRI dhan 43 .
\end{abstract}

\section{Keywords}

Irrigation, Rice, Varietal Performance, Nerica, Relative Yield 


\section{Introduction}

Rice (Oryza sativa L.) is the staple food in Bangladesh and also for more than three billion people globally [1]. To feed this huge number of consumers, it needs to cultivate rice at a large scale of area and at a very higher production rate. However, the population of Bangladesh is up surging by about two million every year and expected to increase by another 30 million over the following 20 years. Thus, Bangladesh will demand about 27.26 million tons of rice by 2020 to feed the increased mass of people. On the contrary, total arable land is supposed to be shrinked down to 10.28 million hectares from 11.25 million ha due to settlement and other causes [2]. However, in spite of lots of efforts to escalate productivity, crop loss is stirring at large scale due to several earthly and man-made reasons. Estimates indicate that, more than two hundred million tons of rice is lost every year due to environmental stresses, diseases and pest incidents [3]. Among the environmental stresses, water stress is a major yield restraining factor of rainfed rice, which occupies almost half of the land used for rice production in Asia and in some countries including Bangladesh, Thailand, Laos; it is the dominant rice ecosystem. However, in global aspect, rainfed rice growing areas comprise $45 \%$ of the total cultivated rice growing area where drought in mild, moderate or severe forms occurs in most years [4]. Regrettably, highest loss in this practice also befalls due to drought, for its high requirement of water, thus causing damage to 2.32 million hectares crop per annum [5]. These water stress vulnerability scenarios are likely to be worsen in the future with predicted climate change scenarios, which will also lead to more complex interactions of water stress with other abiotic and biotic stresses. The frequency of water stress varies in timing and severity among locations and years. Among the rice cultivating seasons in Bangladesh viz. Aus, Aman and Boro, Aus rice is mostly cultivated under rainfed condition during April to August where June to July are most important as the crop passes its reproductive stage during this time yet the rainfall is very erratic in nature. Consequently, water stress upsurge occurs and affects translocation of assimilates and grain development in rice which results in loss of yield, particularly during reproductive stage when plants are highly sensitive to water stress [6]. Water stress reduces the grain filling percentage and grain weight, resulting in a significant decrease of grain yield by $11.6 \%$ to approximately $14.7 \%$. Aus rice requires less number of days to mature compared to Aman and Boro. So, it has the capability to escape late season drought [2]. Therefore, prearranged the large area under rainfed rice cultivation system and the increasing prevalence of drought stress in a wide range of cultivation systems because of declining water table depths, improving the Aus rice varieties has a large potential for helping to achieve sustainable rice production. Hence, increasing Aus rice productivity may become substitute the gap in progress due to water scarcity as well as reduce pressure upon groundwater. Henceforth, it is necessary to find out Aus rice genotypes which exhibit the desired characters like short duration, high yield potential and tolerant towards water stress, so that they can be taken for mass scale production 
under rainfed condition. Use of yield as an index for adaptation to water stress in rice [7] may be considered as a reasonable approach, as grain yield is a major attribute of interest in most plant breeding programs. Therefore, selection of rice varieties and breeding lines with high levels of stress tolerance is one of the main challenges for rice research in recent times [8]. With that background problem and opportunity, this research was initiated to assess yield and yield contributing characters and recommend the ones which give higher yield in spite of rainfed condition.

\section{Materials and Methods}

\subsection{Description of Experimental Site}

The experiment was conducted at the research field of Bangabandhu Sheikh $\mathrm{Mu}$ jibur Rahman Agricultural University (BSMRAU), Gazipur 1706 during April to August 2014 to evaluate some Aus rice varieties for their yield performance under rainfed condition. The site was high land and located in Madhupur Tract under Agro Ecological Zone-28. The soil of the experimental site belongs to Salna series representing shallow Red-Brown Tarace soil type which falls under the order of Inceptisols of soil taxonomy [9]. The meteorological data during the study period were recorded from the meteorological station of BSMRAU and was given in Table 1.

\subsection{Experimental Details}

Cultivated fifteen popular Aus rice varieties viz. BR3, BR14, BR16, BR21, BR24, BR26, BRRI dhan27, BRRI dhan42, BRRI dhan43, BRRI dhan48, BRRI dhan55, BRRI dhan57, Nerica1, Nerica10 and NericaABSS (mutant) were used as planting materials. The experiment was laid out in a split plot design with three replications. The number of main plots and sub-plots was 6 and 90 respectively and the size of unit sub-plot was $3 \mathrm{~m} \times 1 \mathrm{~m}$. The experimental treatments viz. water regime as irrigated (irrigation when necessary) and rainfed (dependent on rainfall) were applied in main plots and the varieties were placed into the sub plots. Water regime treatment started at 20 days after sowing (DAS).

Table 1. Month wise meteorological data.

\begin{tabular}{cccccccccccc}
\hline \multirow{2}{*}{$\begin{array}{c}\text { Month } \\
\text { of } 2014\end{array}$} & \multicolumn{3}{c}{ AT $\left({ }^{\circ} \mathrm{C}\right)$} & \multicolumn{3}{c}{ ST in depth $\left({ }^{\circ} \mathrm{C}\right)$} & $\begin{array}{c}\mathrm{H} \\
(\%)\end{array}$ & $\begin{array}{c}\mathrm{R} \\
(\mathrm{mm})\end{array}$ & $\begin{array}{c}\mathrm{E} \\
(\mathrm{mm})\end{array}$ & $\begin{array}{c}\text { AP } \\
(\mathrm{Hg})\end{array}$ & $\begin{array}{c}\mathrm{GWT} \\
(\mathrm{m})\end{array}$ \\
\cline { 2 - 9 } April & 35.48 & 23.71 & 29.6 & 29.61 & 28.41 & 74.63 & 112.64 & 187.02 & 29.91 & 23.22 \\
May & 34.74 & 26.06 & 30.40 & 31.74 & 30.47 & 81.80 & 138.62 & 139.94 & 29.87 & 23.00 \\
June & 32.75 & 26.63 & 29.69 & 31.61 & 30.06 & 84.33 & 322.33 & 97.19 & 29.82 & 23.00 \\
July & 33.06 & 27.22 & 30.14 & 32.11 & 30.62 & 85.19 & 229.69 & 103.91 & 14.38 & 22.84 \\
August & 31.75 & 26.90 & 29.33 & 29.77 & 28.98 & 83.96 & 420.05 & 84.57 & 00.00 & - \\
\hline
\end{tabular}

Here, $\mathrm{AT}=$ Air Temperature; $\mathrm{ST}=$ Soil Temperature; $\mathrm{H}=$ Humidity; $\mathrm{R}=$ Rainfall; $\mathrm{E}=$ Evaporation; $\mathrm{AP}=$ Atmospheric Pressure and GWT $=$ Ground Water Table. 


\subsection{Operations}

The land preparation was done by repeated ploughing and cross-ploughing with a tractor drawn disc plough and then harrowed. Each ploughing was done followed by laddering for breaking the clods, leveling the lands and collecting the stubbles and removing the weeds. Rainfed plots were protected by polythene sheet to control entry of irrigation water. Healthy and vigorous seeds were collected from Bangladesh Rice Research Institute (BRRI). The selected seeds were soaked in water for 24 hours and then these were kept in gunny bags. The seed started sprouting after 48 hours and almost all seeds were sprouted after 72 hours. Three rice seeds.hill ${ }^{-1}$ was sown maintaining $20 \mathrm{~cm} \times 15 \mathrm{~cm}$ spacing in line by hand on 9 April 2014. After sowing of seeds, light irrigation was provided to ensure uniform establishment of plants. A basal dose of $\mathrm{P} \mathrm{K}$ and $\mathrm{S}$ at the rate of 80,110 and $100 \mathrm{~kg} \cdot \mathrm{ha}^{-1}$ was applied respectively. Nitrogen fertilizer was applied at the rate of $175 \mathrm{~kg} \cdot \mathrm{ha}^{-1}$ in three splits. First split as basal dose and rest at 35 DAS and 55 DAS. Gap filling was done 15 DAS for maintaining the optimum plant population. Hand weeding was done at 15, 35, 55 and 75 DAS to keep the field weed free. Rice bug (Leptocorisa acuta) was controlled instantly by using insecticide Diazinon60EC@3 ml/L at 65 DAS by successive two sprays at seven days intervals.

\subsection{Data Collection}

The crop varieties were harvested from 100 to 130 DAS when the grains attained full maturity. Ten hills were randomly sampled from each sub-plot (outside the area selected for final harvest) for recording necessary data. At maturity (when $90 \%$ of the grains became golden yellow in color), one square meter area from each sub-plot was randomly selected from the central portion and cut manually from the ground level to measure grain and straw yields. The harvested crops of each plot were separately bundled, properly tagged and then brought to the threshing floor. The harvested crops were threshed manually. The grains were cleaned and dried to around $14 \%$ moisture content. Final grain yields plot $^{-1}$ were recorded and converted to tha ${ }^{-1}$. Data were collected for number of effective and non-effective tillers.hill ${ }^{-1}$, number of filled and unfilled grains panicle ${ }^{-1}$, panicle length $(\mathrm{cm})$, test weight $(\mathrm{g})$, grain yield $\left(\mathrm{t} \cdot \mathrm{ha}^{-1}\right)$ and harvest index $(\%)$.

The formula used for different parameters:

Grain yield at $4 \%$ moisture

$=\frac{(100-\text { Sample moisture content }(\%) \times \text { fresh weight of grain }(\mathrm{t} / \mathrm{ha})}{(100-14)}$,

Biological yield $=$ Grain yield + Straw yield,

Harvest index $(\%)=\frac{\text { Grain yield } \times 100}{(\text { Grain yield }+ \text { Straw yield })}$,

$\%$ Reduction $=\frac{\text { Irrigated data }- \text { rainfed data }}{\text { irrigated data }} \times 100$. 


\subsection{Data Analysis}

The data were analyzed statistically and the differences among treatment means were adjudged by least significant difference (LSD) test at 5\% level of significance [10]. Analysis was done with the help of statistical analysis package program Statistix 10.

\section{Results}

\subsection{Contribution of Yield Components}

Tillering is an important agronomic trait for rice production (Badshah et al., 2014) and the number of productive tillers depends on planting density, genotypes and its environment. An effective tiller means the tillers that produce panicle. Effective and non-effective tillers of tested varieties were significantly influenced by irrigated and rainfed treatment (Table 2). Among the tested varieties, the maximum number of effective tillers.hill ${ }^{-1}$ (25.32 and 22.33) was found in BRRI dhan27 which was statistically different from others and the minimum was (9.14 and 6.54) noticed in Nerical which was statistically akin to Nerica10 under both irrigated and rainfed treatment respectively. However, the highest relative number of effective tillers.hill ${ }^{-1}$ was found in BRRI dhan55 (reduction was only $7.22 \%$ ).

Table 2. Effect of irrigated and rainfed condition on effective and non-effective tillers.hill ${ }^{-1}$ of Aus rice varieties

\begin{tabular}{|c|c|c|c|c|c|c|}
\hline \multirow{2}{*}{ Varieties } & \multicolumn{3}{|c|}{ Effective tillers $\cdot$ hill $^{-1}$} & \multicolumn{3}{|c|}{ Non-effective tillers $\cdot$ hill $^{-1}$} \\
\hline & irrigated & rainfed & $\%$ reduction & irrigated & rainfed & $\%$ reduction \\
\hline BR3 & $20.24 c$ & $18.32 \mathrm{c}$ & 9.48 & $2.84 \mathrm{~b}$ & $3.74 \mathrm{~b}$ & -31.69 \\
\hline BR14 & $16.80 \mathrm{e}$ & $14.88 \mathrm{~d}$ & 11.42 & $1.91 \mathrm{~d}$ & $0.97 \mathrm{fg}$ & 49.21 \\
\hline BR16 & $17.56 \mathrm{~d}$ & $14.26 \mathrm{~d}$ & 18.79 & $1.08 \mathrm{~d}$ & $2.84 \mathrm{c}$ & -162.96 \\
\hline BR21 & $14.71 \mathrm{e}$ & $13.54 \mathrm{de}$ & 7.95 & $0.78 \mathrm{f}$ & $2.14 \mathrm{~d}$ & -174.35 \\
\hline BR24 & $20.35 c$ & $17.86 \mathrm{c}$ & 12.23 & $1.68 \mathrm{~d}$ & $2.30 \mathrm{~d}$ & -36.90 \\
\hline BR26 & $20.20 c$ & $14.87 \mathrm{~d}$ & 26.38 & $1.67 \mathrm{~d}$ & $1.33 \mathrm{f}$ & 20.36 \\
\hline BRRI dhan27 & $25.32 \mathrm{a}$ & $22.33 \mathrm{a}$ & 11.81 & $4.03 \mathrm{a}$ & $2.87 c$ & 28.78 \\
\hline BRRI dhan 42 & $18.24 \mathrm{~d}$ & $15.17 \mathrm{~d}$ & 16.83 & $1.58 \mathrm{~d}$ & $2.09 \mathrm{~d}$ & -32.27 \\
\hline BRRI dhan43 & $20.41 c$ & $18.24 \mathrm{c}$ & 10.63 & $2.19 \mathrm{c}$ & $2.40 \mathrm{~d}$ & -9.59 \\
\hline BRRI dhan 48 & $21.54 b$ & $19.79 b c$ & 8.12 & $0.43 \mathrm{~g}$ & $2.70 \mathrm{c}$ & -527.91 \\
\hline BRRI dhan55 & $22.98 b$ & $21.32 b$ & 7.22 & $1.97 \mathrm{~d}$ & $1.95 \mathrm{e}$ & 1.02 \\
\hline BRRI dhan57 & $19.7 \mathrm{~cd}$ & $15.27 \mathrm{~d}$ & 22.48 & $1.29 \mathrm{e}$ & $1.26 \mathrm{f}$ & 2.33 \\
\hline Nerical & $9.14 \mathrm{~g}$ & $6.54 \mathrm{~g}$ & 28.45 & $0.82 \mathrm{f}$ & $4.83 a$ & -489.02 \\
\hline Nerica10 & $11.54 \mathrm{fg}$ & $8.25 \mathrm{fg}$ & 28.51 & $0.71 \mathrm{f}$ & $2.67 c$ & -276.05 \\
\hline NericaABSS & $15.41 \mathrm{e}$ & $13.48 \mathrm{de}$ & 12.52 & $1.83 \mathrm{~d}$ & $2.73 c$ & -49.18 \\
\hline CV (\%) & & $7.58,9$. & & & $4.65,7$ & \\
\hline
\end{tabular}

Mean values having the similar letter (s) differ insignificantly whereas mean values having dissimilar letter (s) differ significantly as per DMRT at the 0.05 probability level. 
Again, data presented in Table 3 revealed that the highest number of non-effective tillers.hill ${ }^{-1}$ (4.03) was found in BRRI dhan27 which was statistically different from others and the lowest (0.43) was noticed in BRRI dhan48 under irrigated condition. In contrast, under rainfed, the highest number of non-effective tillers.hill ${ }^{-1}$ (4.83) was found in Nerical which was statistically different from other varieties and the lowest $(0.97)$ was observed in BR14. The highest relative number of non-effective tillers.hill ${ }^{-1}$ was found in BRRI dhan55 (reduction was only $1.02 \%$ from irrigated condition).

Irrigated and rainfed treatment had considerable effect on number of filled and unfilled grains panicle ${ }^{-1}$ of the studied varieties (Table 3). Among the fifteen varieties of Aus rice, the highest (141.90 and 136.21) and the lowest (69.33 and 55.8) number of filled grains panicle ${ }^{-1}$ was recorded in BRRI dhan 27 and in Nerica1 under both irrigated and rainfed conditions respectively. Yet, the highest relative number of filled grains panicle ${ }^{-1}$ was found in BRRI dhan55 (reduction was only $3.71 \%$ ) followed by BRRI dhan 27 .

The highest number of unfilled grains panicle $e^{-1}$ (39.46) was observed in Nerical which was statistically different from other varieties and the lowest (16.53) was observed in BR21 under irrigated condition (Table 3). On the other hand,

Table 3. Effect of irrigated and rainfed condition on filled and unfilled grains panicle ${ }^{-1}$ of Aus rice varieties.

\begin{tabular}{ccccccc}
\hline \multirow{2}{*}{ Varieties } & \multicolumn{3}{c}{ Filled grains panicle $^{-1}$} & \multicolumn{3}{c}{ Unfilled grains panicle $^{-1}$} \\
\cline { 2 - 7 } & irrigated & rainfed & \% reduction & irrigated & rainfed & \% reduction \\
\hline BR3 & $133.14 \mathrm{~b}$ & $118.21 \mathrm{c}$ & 11.21 & $21.93 \mathrm{f}$ & $29.86 \mathrm{fg}$ & -36.16 \\
BR14 & $110.28 \mathrm{e}$ & $106.48 \mathrm{~d}$ & 3.45 & $25.43 \mathrm{de}$ & $34.23 \mathrm{de}$ & -34.60 \\
BR16 & $117.54 \mathrm{~d}$ & $100.14 \mathrm{~d}$ & 14.80 & $24.00 \mathrm{e}$ & $35.40 \mathrm{~cd}$ & -47.50 \\
BR21 & $100.34 \mathrm{f}$ & $88.54 \mathrm{e}$ & 11.76 & $16.53 \mathrm{~h}$ & $27.50 \mathrm{hi}$ & -66.36 \\
BR24 & $113.41 \mathrm{de}$ & $103.18 \mathrm{~d}$ & 9.02 & $27.03 \mathrm{~d}$ & $36.63 \mathrm{bc}$ & -35.52 \\
BR26 & $107.63 \mathrm{e}$ & $97.57 \mathrm{~d}$ & 9.34 & $24.83 \mathrm{de}$ & $33.56 \mathrm{de}$ & -35.16 \\
BRRI dhan27 & $141.90 \mathrm{a}$ & $136.21 \mathrm{a}$ & 4.01 & $21.80 \mathrm{f}$ & $27.23 \mathrm{fg}$ & -24.91 \\
BRRI dhan42 & $108.16 \mathrm{e}$ & $94.9 \mathrm{de}$ & 12.25 & $31.20 \mathrm{~b}$ & $40.97 \mathrm{bc}$ & -31.31 \\
BRRI dhan43 & $127.16 \mathrm{c}$ & $114.59 \mathrm{c}$ & 9.89 & $24.56 \mathrm{e}$ & $42.10 \mathrm{~b}$ & -71.42 \\
BRRI dhan48 & $130.21 \mathrm{~b}$ & $114.24 \mathrm{c}$ & 12.26 & $26.60 \mathrm{de}$ & $35.80 \mathrm{~cd}$ & -34.59 \\
BRRI dhan55 & $128.93 \mathrm{c}$ & $124.15 \mathrm{~b}$ & 3.71 & $27.80 \mathrm{~d}$ & $39.83 \mathrm{bc}$ & -43.27 \\
BRRI dhan57 & $130.54 \mathrm{~b}$ & $118.1 \mathrm{c}$ & 9.53 & $18.83 \mathrm{gh}$ & $29.36 \mathrm{fg}$ & -55.92 \\
Nerica1 & $69.33 \mathrm{~g}$ & $55.8 \mathrm{~g}$ & 19.51 & $39.46 \mathrm{a}$ & $56.20 \mathrm{a}$ & -42.42 \\
Nerica10 & $102.3 \mathrm{f}$ & $79.27 \mathrm{f}$ & 22.51 & $29.13 \mathrm{c}$ & $43.73 \mathrm{~b}$ & -50.12 \\
NericaABSS & $105.97 \mathrm{e}$ & $94.33 \mathrm{de}$ & 10.98 & $30.70 \mathrm{bc}$ & $33.17 \mathrm{ef}$ & -8.05 \\
CV (\%) & & $6.73,9.46$ & & & $3.48,7.25$ & \\
\hline
\end{tabular}

Mean values having the similar letter (s) differ insignificantly whereas mean values having dissimilar letter (s) differ significantly as per DMRT at the 0.05 probability level. 
Nerica1 produced the highest number of unfilled grains panicle ${ }^{-1}$ (56.20) which didn't show statistical harmony with other varieties and the lowest number of unfilled grains panicle $^{-1}$ (27.33) was observed in BRRI dhan27 under rainfed. However, the maximum relative number of unfilled grains panicle ${ }^{-1}$ was observed in NericaABSS (reduction was only by $8.05 \%$ ) followed by BRRI dhan 27 .

Panicle length and test weight contributed much to increase of grain yield. Data presented in Table 4 exerted meaningful effect on panicle length and test weight by irrigated and rainfed condition. The highest panicle length $(28.77 \mathrm{~cm}$ and $26.93 \mathrm{~cm}$ ) was measured in BRRI dhan 27 which was statistically different from others and the lowest was $(21.10 \mathrm{~cm}$ and $20.23 \mathrm{~cm})$ obtained from Nerical under both irrigated and rainfed respectively. However, the highest relative panicle length was found in NericaABSS (reduction was only 1.70\%) followed by Nerica10.

Among the varieties, the highest test weight $(29.97 \mathrm{~g})$ was found in BRRI dhan27 which was statistically similar with BR3 and the lowest 1000-grain weight (19.23 g) was observed in BR26 which showed statistical harmony with BR21 under irrigated (Table 4). In contrast, under rainfed the highest test weight $(29.23 \mathrm{~g})$ was also found in BRRI dhan27 and the lowest (19.34 g) was found in

Table 4. Effect of irrigated and rainfed condition on panicle length and test weight of Aus rice varieties.

\begin{tabular}{ccccccc}
\hline \multirow{2}{*}{ Varieties } & \multicolumn{5}{c}{ Panicle length } & \multicolumn{3}{c}{ Test weight } \\
\cline { 2 - 7 } & irrigated & rainfed & \% reduction & irrigated & rainfed & \% reduction \\
\hline BR3 & $25.17 \mathrm{~b}$ & $24.09 \mathrm{~b}$ & 4.29 & $28.25 \mathrm{ab}$ & $27.67 \mathrm{~b}$ & 2.05 \\
BR14 & $24.29 \mathrm{c}$ & $23.57 \mathrm{c}$ & 2.96 & $27.84 \mathrm{~b}$ & $26.21 \mathrm{~b}$ & 5.85 \\
BR16 & $25.13 \mathrm{~b}$ & $24.18 \mathrm{~b}$ & 3.78 & $25.35 \mathrm{c}$ & $24.41 \mathrm{c}$ & 3.71 \\
BR21 & $24.11 \mathrm{c}$ & $22.53 \mathrm{~d}$ & 6.55 & $20.67 \mathrm{ef}$ & $19.84 \mathrm{f}$ & 4.02 \\
BR24 & $24.79 \mathrm{bc}$ & $23.19 \mathrm{c}$ & 6.45 & $22.84 \mathrm{e}$ & $21.47 \mathrm{e}$ & 5.99 \\
BR26 & $23.72 \mathrm{~d}$ & $22.19 \mathrm{~d}$ & 6.45 & $19.23 \mathrm{f}$ & $19.34 \mathrm{f}$ & -0.57 \\
BRRI dhan27 & $28.77 \mathrm{a}$ & $26.93 \mathrm{a}$ & 6.39 & $29.97 \mathrm{a}$ & $29.23 \mathrm{a}$ & 2.46 \\
BRRI dhan42 & $22.73 \mathrm{e}$ & $21.11 \mathrm{e}$ & 7.12 & $22.35 \mathrm{e}$ & $21.29 \mathrm{e}$ & 4.74 \\
BRRI dhan43 & $23.99 \mathrm{~d}$ & $21.85 \mathrm{e}$ & 8.92 & $23.39 \mathrm{~d}$ & $21.58 \mathrm{e}$ & 7.7 \\
BRRI dhan48 & $24.69 \mathrm{c}$ & $22.97 \mathrm{~d}$ & 6.97 & $23.75 \mathrm{~d}$ & $21.50 \mathrm{e}$ & 9.47 \\
BRRI dhan55 & $25.76 \mathrm{~b}$ & $24.19 \mathrm{~b}$ & 6.09 & $24.76 \mathrm{~cd}$ & $24.21 \mathrm{c}$ & 2.22 \\
BRRI dhan57 & $24.87 \mathrm{c}$ & $23.14 \mathrm{c}$ & 6.96 & $23.79 \mathrm{~d}$ & $22.83 \mathrm{~d}$ & 4.04 \\
Nerical & $21.10 \mathrm{f}$ & $20.23 \mathrm{f}$ & 4.12 & $26.62 \mathrm{bc}$ & $25.16 \mathrm{bc}$ & 5.48 \\
Nerica10 & $23.15 \mathrm{~d}$ & $22.62 \mathrm{~d}$ & 2.29 & $23.45 \mathrm{~d}$ & $22.19 \mathrm{~d}$ & 5.37 \\
NericaABSS & $24.08 \mathrm{c}$ & $23.67 \mathrm{c}$ & 1.70 & $23.91 \mathrm{~d}$ & $22.64 \mathrm{~d}$ & 5.31 \\
CVV (\%) & & $4.55,5.02$ & & & $2.81,3.36$ & \\
\hline & & & & & \\
\hline
\end{tabular}

Mean values having the similar letter (s) differ insignificantly whereas mean values having dissimilar letter (s) differ significantly as per DMRT at the 0.05 probability level. 
BR26 which was statistically identical to BR21. And yet, the highest relative 1000-grain weight was found in BR3 (reduction was only 2.05\%) followed by BRRI dhan 55 .

The major factor of increasing harvest index (HI) is to increase economic yield. In the present study Table 5 showed that the highest HI (45.66\%) was found in BRRI dhan 27 which was statistically similar with BRRI dhan 55 and the lowest HI (34.60\%) was observed in Nerical which was statistically different from others under irrigated treatment.

In contrast, the maximum HI (44.64\%) was noticed in BRRI dhan27 which was statistically identical to BRRI dhan48, BRRI dhan 55 and the minimum HI (33.33\%) was recorded in Nerical which was statistically diverse from other varieties under rainfed. However, the highest relative HI was found in BRRI dhan42 (reduction was only $0.26 \%$ ) followed by BRRI dhan 57 .

\subsection{Ranking of Tested Varieties Based on Grain Yield}

Final yield is the product of cumulative seasonal absorption of radiation, radiation use efficiency and the portion of total biomass that goes to grain (harvest index). Yield is a complex phenomenon and influenced by several factors. Yield

Table 5. Effect of irrigated and rainfed condition on grain yield and harvest index of Aus rice varieties.

\begin{tabular}{cccc}
\hline & \multicolumn{3}{c}{ Harvest index (\%) } \\
\cline { 2 - 4 } Varieties & irrigated & rainfed & \% reduction \\
\hline BR3 & $43.10 \mathrm{c}$ & $42.55 \mathrm{c}$ & 1.28 \\
BR14 & $42.55 \mathrm{~d}$ & $41.15 \mathrm{~d}$ & 3.29 \\
BR16 & $42.02 \mathrm{~d}$ & $41.15 \mathrm{~d}$ & 2.07 \\
BR21 & $42.66 \mathrm{~d}$ & $40.65 \mathrm{e}$ & 4.71 \\
BR24 & $41.32 \mathrm{e}$ & $40.48 \mathrm{e}$ & 2.03 \\
BR26 & $41.67 \mathrm{e}$ & $40.32 \mathrm{e}$ & 3.24 \\
BRRI dhan27 & $45.66 \mathrm{a}$ & $44.64 \mathrm{a}$ & 2.23 \\
BRRI dhan42 & $42.13 \mathrm{~d}$ & $42.02 \mathrm{c}$ & 0.26 \\
BRRI dhan43 & $43.67 \mathrm{bc}$ & $42.92 \mathrm{c}$ & 1.72 \\
BRRI dhan48 & $44.44 \mathrm{~b}$ & $44.05 \mathrm{a}$ & 0.87 \\
BRRI dhan55 & $45.05 \mathrm{a}$ & $44.64 \mathrm{a}$ & 0.91 \\
BRRI dhan57 & $43.49 \mathrm{c}$ & $43.10 \mathrm{~b}$ & 0.89 \\
Nerica1 & $34.60 \mathrm{~g}$ & $33.33 \mathrm{~g}$ & 3.67 \\
Nerica10 & $36.76 \mathrm{f}$ & $35.59 \mathrm{f}$ & 3.18 \\
NericaABSS & $41.32 \mathrm{e}$ & $40.82 \mathrm{e}$ & 1.21 \\
CV (\%) & & $2.43,3.76$ & \\
\hline & & & \\
\hline
\end{tabular}

Mean values having the similar letter (s) differ insignificantly whereas mean values having dissimilar letter (s) differ significantly as per DMRT at the 0.05 probability level. 
of cereals entirely depends on maximum effective tiller formation, filled grains per panicle, panicle length etc. which rely on availability of water in the field. The ranking of rice genotypes based on their grain yield production under irrigated and rainfed conditions is given in Table 6.

It is obvious from the result that most of the genotypes exhibited yield stability under changing growth environment by maintaining almost equal ranking under both irrigated and rainfed conditions, except a few, e.g. BR16. However, the ranking of relative grain yield (\% yield under rainfed condition in relation to irrigated condition) was not following that of absolute yield under both the growing conditions.

For instance, BRRI dhan 27 ranked the top under both irrigated and rainfed conditions, but the relative yield was the maximum in case of BRRI dhan55 (reduction was only $3.59 \%$ ) followed by Nerica10. Though the relative yield is important consideration for physiologist to understand the yield loss mechanisms due to water shortage, absolute productivity is the main consideration for the cultivators and from the agronomic point of view. Therefore, considering the yield stability and absolute yield performance BRRI dhan 27 may be considered especially for Aus rice cultivation followed by BRRI dhan55, BRRI dhan 48 and BRRI dhan 43 .

Table 6. Ranking of varieties based on grain yield under irrigated and rainfed conditions.

\begin{tabular}{|c|c|c|c|c|c|}
\hline \multirow{2}{*}{ Varieties } & \multicolumn{4}{|c|}{ Grain yield $\left(\mathrm{t} \cdot \mathrm{ha}^{-1}\right)$} & \multirow{2}{*}{$\%$ reduction } \\
\hline & irrigated & rank & rainfed & rank & \\
\hline BRRI dhan27 & $2.47 \mathrm{a}$ & 1 & $2.26 \mathrm{a}$ & 1 & 8.50 \\
\hline BRRI dhan55 & $1.95 \mathrm{~b}$ & 2 & $1.88 \mathrm{~b}$ & 2 & 3.59 \\
\hline BRRI dhan 48 & $1.90 \mathrm{bc}$ & 3 & $1.79 \mathrm{c}$ & 3 & 5.79 \\
\hline BRRI dhan 43 & $1.88 \mathrm{c}$ & 4 & $1.71 \mathrm{~cd}$ & 4 & 9.04 \\
\hline BR3 & $1.88 \mathrm{c}$ & 4 & $1.67 \mathrm{~d}$ & 6 & 11.17 \\
\hline BRRI dhan57 & $1.86 \mathrm{c}$ & 5 & $1.69 \mathrm{~d}$ & 5 & 9.14 \\
\hline BR16 & $1.70 \mathrm{~d}$ & 6 & $1.41 \mathrm{e}$ & 10 & 17.06 \\
\hline BR14 & $1.68 \mathrm{~d}$ & 7 & $1.44 \mathrm{e}$ & 7 & 14.29 \\
\hline BR24 & $1.61 \mathrm{e}$ & 8 & $1.42 \mathrm{e}$ & 9 & 11.80 \\
\hline BR21 & $1.58 \mathrm{e}$ & 9 & $1.37 \mathrm{f}$ & 11 & 13.30 \\
\hline BR26 & $1.57 \mathrm{e}$ & 10 & $1.43 \mathrm{e}$ & 8 & 8.92 \\
\hline BRRI dhan 42 & $1.53 \mathrm{e}$ & 11 & $1.32 \mathrm{~g}$ & 13 & 13.73 \\
\hline NericaABSS & $1.52 \mathrm{e}$ & 12 & $1.37 \mathrm{f}$ & 12 & 9.87 \\
\hline Nerica10 & $1.31 \mathrm{f}$ & 13 & $1.26 \mathrm{~g}$ & 14 & 3.82 \\
\hline Nerical & $1.22 \mathrm{~g}$ & 14 & $1.13 \mathrm{~h}$ & 15 & 7.38 \\
\hline CV (\%) & & & $4.19,6$ & & \\
\hline
\end{tabular}

Mean values having the similar letter (s) differ insignificantly whereas mean values having dissimilar letter (s) differ significantly as per DMRT at the 0.05 probability level. 


\subsection{Correlation between Effective Tillers and Yield}

There has been observed significant correlation between numbers of effective tillers and grain yield (Figure 1). Yield was increased due to profuse number of effective tillers.

\subsection{Correlation between Filled Grains Panicle ${ }^{-1}$ and Yield}

Results illustrated in Figure 2 indicated that there was significant correlation between numbers of filled grains panicle ${ }^{-1}$ and grain yield. Yield was increased due to the production of considerable number of filled grains panicle ${ }^{-1}$.

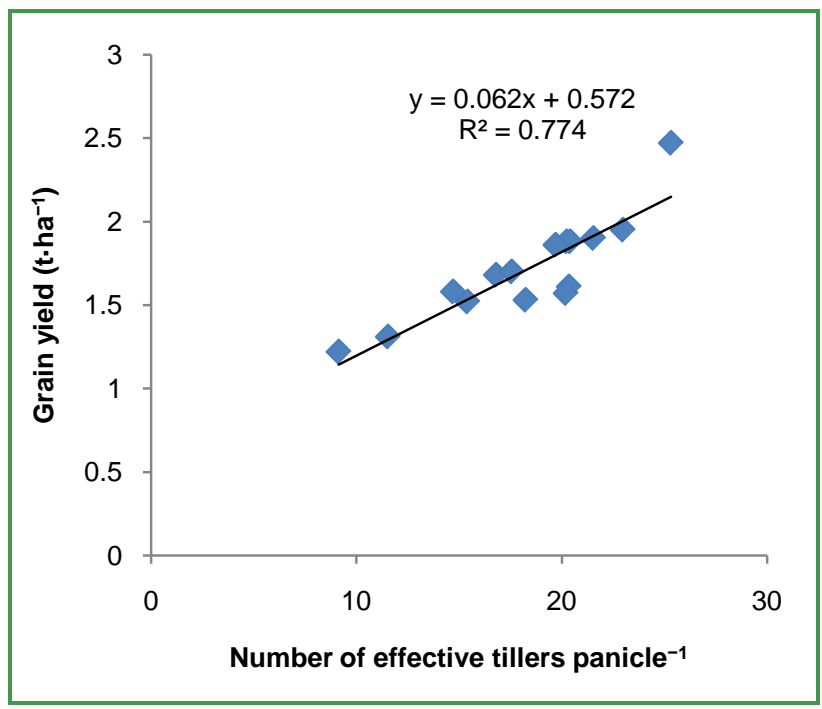

(a)

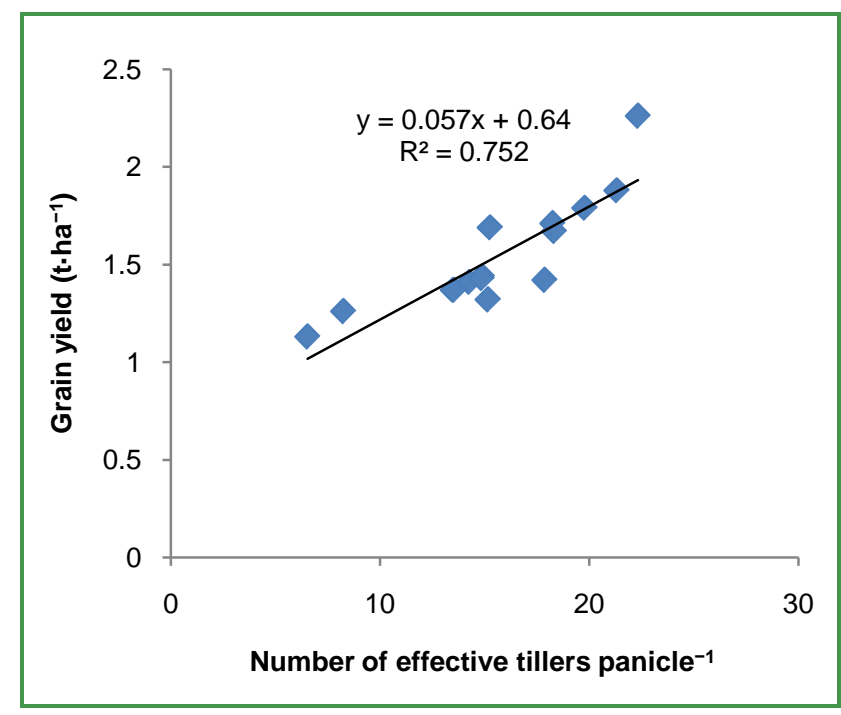

(b)

Figure 1. Correlation between number of effective tillers panicle ${ }^{-1}$ and grain yield under irrigated and rainfed condition. (a) Irrigated; (b) Rainfed.

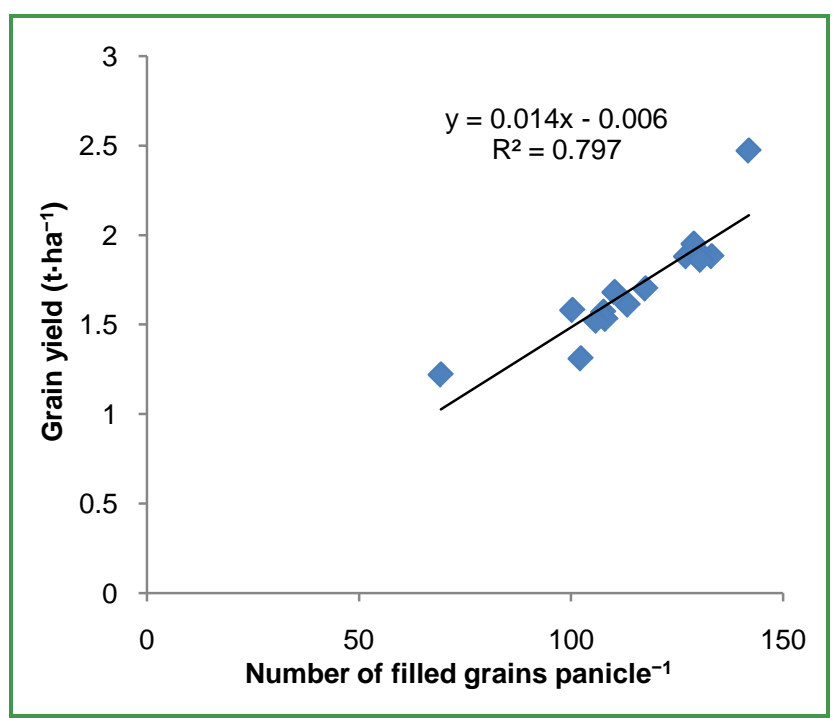

(a)

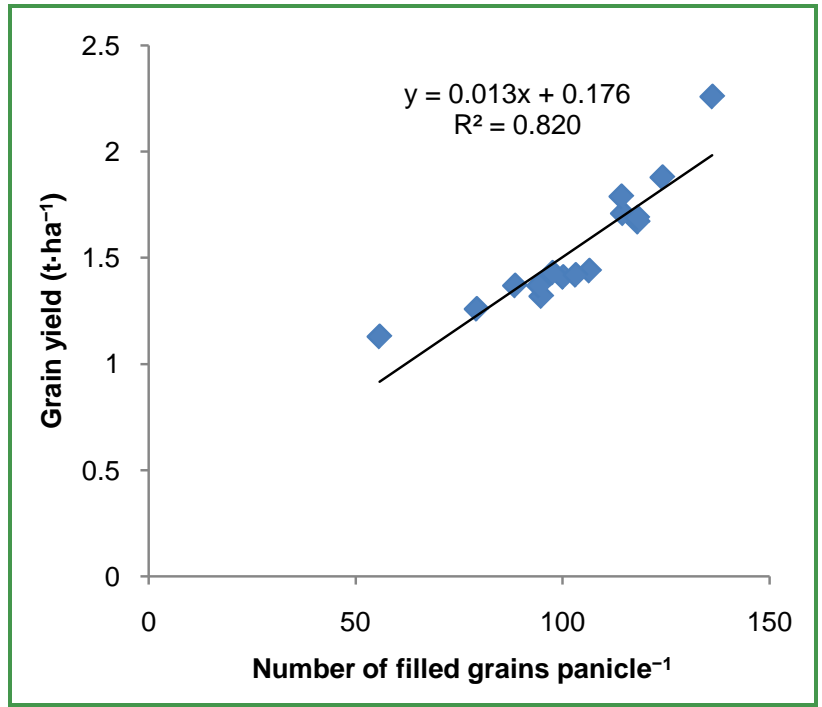

(b)

Figure 2. Correlation between number of filled grains panicle ${ }^{-1}$ and grain yield under irrigated and rainfed condition. (a) Irrigated; (b) Rainfed. 


\subsection{Correlation between Days of Panicle Initiation and Yield}

There was also seen noteworthy correlation between duration of reproductive period and grain yield (Figure 3). The more the duration of reproductive stage, the more will be the yield.

\section{Discussion}

Significant differences for all traits due to irrigated and rainfed treatment amongst the Aus rice varieties have been noticed. Those differences were occurred might be due to improper distribution of rainwater and due to prevailing high temperature during the crop cycle particularly early growth stages that caused a relatively higher evapotranspiration rate during the entire crop cycle. In the meantime, air temperature as well as the soil temperature was higher which made the crops difficult to uptake lesser amount of water and minerals required for plants growth and development. The impact of water regime was considerably important for varietal performance. The effect of water stress may vary with genotypes as well as growing environment of the crop. It indicates that there is sufficient scope to select the promising genotypes from the present study for yield and some other economic plant traits.

The number of effective tillers was higher under irrigated condition. Water influences to increase tiller numbers of the varieties by upholding cell turgidity and it is the fundamental input for occurring photosynthesis as well as acts as a major integral of tissue, an element in chemical reaction, a solvent for and mode of translocation for metabolites and minerals within the plant body. Besides these function, it is also essential for cell enlargement through increasing turgor pressure ultimately accelerating growth and development of the number of effective tillers. Another reason might be due to maintaining relatively higher water potential outside the plant which is necessary for absorbing water with minerals by the plant roots as well as due to receiving water from both irrigation and

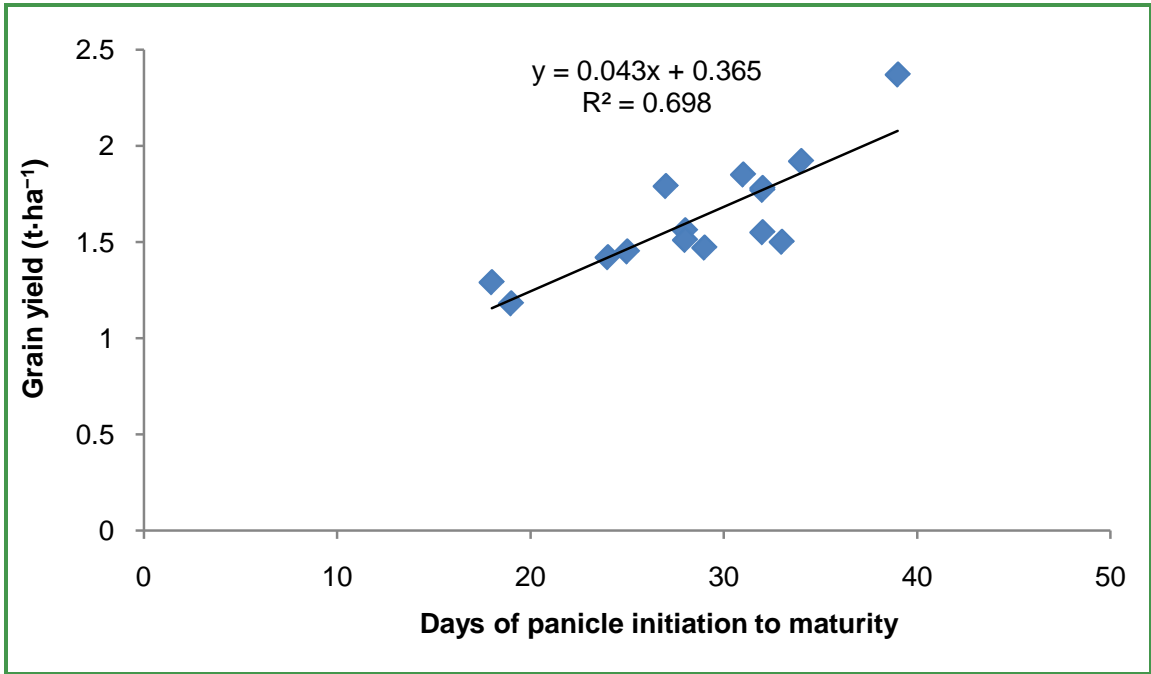

Figure 3. Correlation between days of panicle initiation to maturity and grain yield. 
rainfall. In contrast, the lowest number of effective tillers was observed under rainfed condition might be due to lack of available soil moisture and due to have reduced transpiration rate with a view to conserving water for their survival and also for having low relative water content of the cells [11] [12] [13] [14] [15]. Another reason might be due to prevalent high temperature during the period of formation of tillers which eventually increased evapotranspiration rate and lowered the differences of water potential gradient. However, water deficit caused impaired mitosis, cell elongation and expansion resulted in decreased growth of the number of tillers [16] and induced lesser number of effective tillers which affects its yield [17] [18]. Results are agreed with the findings of [19] and stated that plants produced lower number of effective tillers when subjected to water stress (Table 2).

From the Table 2 it is noticed that the highest number of non-effective tillers was observed in rainfed due to the reduction in turgor pressure under stress and finally cell growth of the tillers was severely impaired [20]. Water stress affects both expansion as well as enlargement of growth [21] of the tillers thus producing a large number of non-effective tillers. It interrupts plant net photosynthesis [19] [22], rate of transpiration [23], stomatal conductance [24], water use efficiency [25], intercellular carbon-dioxide, photosystem-II activity [26], relative water content of the cell [25] [27] [28] and ultimately membrane stability index [29]. All of these factors reduce under water shortage in rice plant [30] [31] [32].

The higher number of filled grains panicle ${ }^{-1}$ was recorded under irrigated condition might be due to effective translocation of substantial amount of photo-assimilates from source to sinks and due to have produced profuse number of effective tillers (Table 3). On the contrary, filled grains were reduced in rainfed condition due to produce less number of effective tillers as well as reduced transpirational water loss for their subsistence. Another reason might be due to having high air and soil temperature, high evaporation during early growth stages of the crops. Similar results were found by several scientists [33] [34] [35].

The number of unfilled grains was followed an increasing trend under rainfed treatment (Table 3) might be due to reduced photosynthetic rate of the varieties and due to the production of less number of effective tillers and filled grains as well as due to causing spikelet sterility that ultimately lead to unfilled grains [36]. Increase in spikelet sterility [29] [37] is commonly observed under water stress. Results are in agreement with the findings by some scientists [38] [39].

Panicle length was also greater due to get ample water in addition to have adequate assimilates which was required for increasing length of panicle in irrigated state (Table 4). In contrast, Panicle length was reduced in rainfed due to shortage of photo-assimilates production resulting stunted growth and due to have lower water potential around the plants roots compared to plant body. Water stress reduces panicle length [17] [18] [39]. Results are endorsed with the findings of [40].

Under irrigated condition test weight was higher due to uniform grain and 
also for having lesser number of shriveled grains as well as varieties were capable to mobilize their assimilates to the economic portion i.e. grain (Table 4). In contrast, reduction in grain size, weight [6] [14] [41], rate of seed-setting and test weight [42] are commonly noticed under water deficit condition. Results are agreed with the findings of [35]. Thousand-grain weight and grain yield were decreased with increasing water stress levels [40] [43] [44] [45]. Water deficit at vegetative growth particularly booting stage [46], flowering and terminal phases can interrupt commencement of floret, triggering spikelet sterility and slow grain filling, resulted in lower grain weight [36] [42] [47].

The ultimate purpose of growing crops is to fetch greater amount of harvestable yield. Under irrigated situation adequate water allowing high stomatal conductance and transport of $\mathrm{CO}_{2}$ into leaves, thus produced a large quantity of photosynthates (Table 6). In that condition plant produced larger leaf area, more number of effective tillers and filled grains, increased test weight and less number of unfilled grains and irrigation water as well as rainwater necessary for functioning normal metabolic activities of the plants whereas in rainfed condition plant produced smaller leaf area, effective tillers, filled grains and more number of unfilled grains. Nevertheless, chlorophyll content and rate of photosynthesis of the flag leaves declined more quickly in water deficit condition resulting reduction in grain yield [48]. Water stress reduces grain yield probably by shortening the grain filling period [38], troublemaking leaf gas exchange properties, restraining the size of the source and sink tissues, impaired phloem loading and translocation of assimilate [49]. The reduction in yield may also be due to drought stimulated reduction in rates of $\mathrm{CO}_{2}$ assimilation, reduced conductivity of stomata, photosynthetic pigments, tiny leaf size, disturbed plant water relations, reduction in water use efficiency, reduction in activities of enzymes of sucrose and starch synthesis and reduced photo-assimilate partitioning, leading to a reduction in plant growth and yield [50]. The amount of grain yield loss depends on the duration of shortage of water, the crop growth phase [51] as well as the existing water stress condition [29]. Grain yield of rice severely decreases under water deficit condition [22] [28] [52] [53]. Results are concurred with the findings of numerous researchers [21] [28] [37] [54]-[61].

Under irrigated condition the maintenance of reproductive growth around the time of flowering allowed the maintenance of capability for storing of photo-assimilates later in the crop cycle, thereby increasing trend of harvest index was seen in that condition (Table 5). Water stress at flowering and grain filling resulted in lower $\mathrm{HI}$ than water stress at tillering and no stress control which are statistically similar with higher HI. Decrease in HI could be largely due to water stress which resulted to decrease in translocation of assimilates to the grains, which lowered grain weight and increased the empty grains. High HI indicate the efficient translocation of assimilates towards sink. Lower HI values under water stress at flowering and grain filling stages indicate that it was more harmful in translocation of assimilates towards the grains. This finding is in accord 
with that observed by [62]. Harvest index was higher in irrigation treatment compared to rainfed as application of water encouraged growth of large number of effective tillers, produced more amount of assimilates, less number of non-effective tillers and ultimately substantial grain yield of Aus rice. Henceforth, harvest index exhibited maximum positive direct effect on grain yield [63]. However, harvest index and yield were decreased in water stress condition [34] [35] [64].

\section{Correlation between Effective Tillers and Filled Grains along with Grain Yield}

Yield was increased due to profuse number of effective tillers and due to the production of considerable number of filled grains panicle ${ }^{-1}$. Reference [65] also reported that, higher numbers of effective tillers are positively correlated with higher yield. Reference [66] testified that, the number of effective tillers rather than total number of tillers contributes more to enhance productivity of rice plant.

\section{Conclusion}

All of the yield parameters had exerted decreasing trend under rainfed condition. In the present study the tolerance of rice genotypes subjected to rainfed or water stress varied remarkably. Based on the results it can be concluded that BRRI dhan27, BRRI dhan55, BRRI dhan 48 and BRRI dhan 43 showed the highest effective tillers, filled grains ultimately grain yield in the both growth environment. In case of yield, BRRI dhan 27 ranked the top under both irrigated and rainfed conditions, yet the relative yield was the maximum in BRRI dhan55 followed by Nerika10. Therefore, based on the yield stability and absolute yield performance BRRI dhan 27 may be considered satisfactorily for Aus rice cultivation, followed by BRRI dhan55, BRRI dhan 48 and BRRI dhan43. Farmers could cultivate BRRI dhan 27 for the purpose of higher yield under water limiting area.

\section{References}

[1] Abodolereza, A. and Racionzer, P. (2009) Food Outlook: Global Market Analysis. FAO, Rome, 23-27.

[2] BRRI (Bangladesh Rice Research Institute) (2011) Adhunik Dhaner Chash. Bangladesh Rice Research Institute, Joydebpur, Gazipur, 5. (In Bengali)

[3] Chen, T.H. and Murata, N. (2002) Enhancement of Tolerance of Abiotic Stress by Metabolic Engineering of Betaines and Other Compatible Solutes. Current Opinion in Plant Biology, 5, 250-257. https://doi.org/10.1016/S1369-5266(02)00255-8

[4] Kumar, A. (2012) Drought Yield Index to Select High Yielding Rice Lines under Different Drought Stress Severities. Rice, 5, 1-12.

[5] Habiba, U., Shaw, R. and Takeuchi, Y. (2011) Drought Risk Reduction through a Socio-Economic, Institutional and Physical Approach in the Northwestern Region of Bangladesh. Environmental Hazards, 10, 121-138. https://doi.org/10.1080/17477891.2011.582311

[6] Venuprasad, R., Lafitte, H.R. and Atlin, G.N. (2007) Response to Direct Selection 
for Grain Yield under Drought Stress in Rice. Crop Science, 47, 285-293. https://doi.org/10.2135/cropsci2006.03.0181

[7] Atlin, G.N. (2001) Breeding for Suboptimal Environments. In: Shu, F. and Jaya, B., Eds., Increased Lowland Rice Production in the Mekong Region: Proceedings of the International Workshop, Held in Vientiane, Laos, 30 October-2 November 2000. ACIAR, Canberra, Australia, 245-251.

[8] Serraj, R. and Atlin, G. (2008) Drought-Resistant Rice for Increased Rainfed Production and Poverty Alleviation: A Concept Note. 385-400. In: Serraj, R., Bennett, J. and Hardy, B., Eds., Drought Frontiers in Rice: Crop Improvement for Increased Rainfed Production, International Rice Research Institute, Los Baños, Philippines.

[9] Brammer, H. (1978) Rice Soils of Bangladesh. IRRI, Manila, Philippines, 35-55.

[10] Gomez, K.A. and Gomez, A.A. (1984) Statistical Procedure for Agricultural Research. 2nd Edition, John Wiley and Sons, New York, 64.

[11] Badshah, M.A., Naimei, T., Zou, Y., Ibrahim, M. and Wang, K. (2014) Yield and Tillering Response of Super Hybrid Rice Liangyoupeijiu to Tillage and Establishment Methods. The Crop Journal, 2, 79-86. http://dx.doi.org/10.1016/j.cj.2013.11.004

[12] Bunnag, S. and Pongthai, P. (2013) Selection of Rice (Oryza sativa L.) Cultivars Tolerant to Drought Stress at the Vegetative Stage under Field Conditions. American Journal of Plant Sciences, 4, 1701-1708. http://dx.doi.org/10.4236/ajps.2013.49207

[13] Ashfaq, M., Haider, M.S., Khan, A.S. and Allah, S.U. (2014) Breeding Potential of the Basmati Rice Germplasm under Water Stress Condition. African Journal of Biotechnology, 11, 6647-6657.

[14] Mostajeran, A. and Rahimi-Eichi, V. (2009) Effects of Drought Stress on Growth and Yield of Rice (Oryza sativa L.) Cultivars and Accumulation of Proline and Soluble Sugars in Sheath and Blades of Their Different Ages Leaves. Agriculture and Environmental Science, 5, 264-272.

[15] Sarvestani, Z.T., Pirdashti, H., Sanavy, S.A.M.M. and Balouchi, H. (2008) Study of Water Stress Effects in Different Growth Stages on Yield and Yield Components of Different Rice (Oryza sativa L.) Cultivars. Pakistan Journal of Biological Sciences, 11, 1303-1309. http://dx.doi.org/10.3923/pjbs.2008.1303.1309

[16] Hussain, M., Malik, M.A., Farooq, M., Ashraf, M.Y. and Cheema, M.A. (2008) Improving Drought Tolerance by Exogenous Application of Glycinebetaine and Salicylic Acid in Sunflower. Journal of Agronomy and Crop Science, 194, 193-199. http://dx.doi.org/10.1111/j.1439-037X.2008.00305.x

[17] Bakul, M.R.A., Akter, M.S., Islam, M.N., Chowdhury, M.M.A.A. and Amin, M.H.A. (2009) Water Stress Effect on Morphological Characters and Yield Attributes in Some Mutants T-Aman Rice Lines. Bangladesh Research Publications Journal, 3 , 934-944.

[18] Sikuku, P.A., Netondo, G.W., Onyango, J.C. and Musyimi, D.M. (2010) Chlorophyll Fluorescence, Protein and Chlorophyll Content of three NERICA Rainfed Rice Varieties under Varying Irrigation Regimes. Agriculture and Biology Journal of North America, 5, 19-25.

[19] Yang, P.M., Huang, Q.C., Qin, G.Y., Zhao, S.P. and Zhou, J.G. (2014) Different Drought-Stress Responses in Photosynthesis and Reactive Oxygen Metabolism between Autotetraploid and Diploid Rice. Photosynthetica, 52, 193-202. http://dx.doi.org/10.1007/s11099-014-0020-2

[20] Taiz, L. and Zeiger, E. (2006) Plant Physiology. 4th Edition, Sinauer Associates, Sunderland, MA, 7-64. 
[21] Shao, H.B., Chu, L.Y., Shao, M.A., Jaleel, C.A. and Mi, H.M. (2008) Higher plant Antioxidants and Redox Signaling under Environmental Stresses. Comptes Rendus Biologies, 331, 433-441. http://dx.doi.org/10.1016/j.crvi.2008.03.011

[22] Centritto, M., Lauteri, M., Monteverdi, M.C. and Serraj, R. (2009) Leaf Gas Exchange, Carbon Isotope Discrimination, and Grain Yield in Contrasting Rice Genotypes Subjected to Water Deficits during the Reproductive Stage. Journal of EXperimental Botany, 60, 2325-2339. http://dx.doi.org/10.1093/jxb/erp123

[23] Cabuslay, G.S., Ito, O. and Alejar, A.A. (2002) Physiological Evaluation of Responses of Rice (Oryza sativa L.) to Water Deficit. Plant Science, 163, 815-827. http://dx.doi.org/10.1016/S0168-9452(02)00217-0

[24] Singh, A., Sengar, K. and Sengar, R.S. (2013) Gene Regulation and Biotechnology of Drought Tolerance in Rice. International Journal of Biotechnology \& Bioengineering, 4, 547-552.

[25] Cha-Um, S., Yooyongwech, S. and Supaibulwatana, K. (2010) Water Deficit Stress in the Reproductive Stage of Four Indica Rice (Oryza sativa L.) Genotypes. Pakistan Journal of Botany, 42, 3387-3398.

[26] Pieters, A.J. and El Souki, S. (2005) Effects of Drought during Grain Filling on PS II Activity in Rice. Journal of Plant Physiology, 162, 903-911. http://dx.doi.org/10.1016/j.jplph.2004.11.001

[27] Biswas, A.K. and Choudhuri, M.A. (1984) Effect of Water Stress at Different Developmental Stages of Field-Grown Rice. Biologia Plantarum, 26, 263-266. http://dx.doi.org/10.1007/BF02902907

[28] Pirdashti, H., Sarvestani, Z.T. and Bahmanyar, M.A. (2009) Comparison of Physiological Responses among Four Contrast Rice Cultivars under Drought Stress Conditions. World Academy of Science, Engineering and Technology, 49, 52-53.

[29] Kumar, S., Dwivedi, S.K., Singh, S.S., Bhatt, B.P., Mehta, P., Elanchezhian, R., Singh, V.P. and Singh, O.N. (2014) Morpho-Physiological Traits Associated with Reproductive Stage Drought Tolerance of Rice (Oryza sativa L.) Genotypes under Rain-Fed Condition of Eastern Indo-Gangetic Plain. Indian Journal of Plant Physiology, 19, 87-93. http://dx.doi.org/10.1007/s40502-014-0075-X

[30] Farooq, M., Kobayashi, N., Ito, O., Wahid, A. and Serraj, R. (2010) Broader Leaves Result in Better Performance of Indica Rice under Drought Stress. Journal of Plant Physiology, 167, 1066-1075. http://dx.doi.org/10.1016/j.jplph.2010.03.003

[31] Ding, L., Li, Y.R., Li, Y., Shen, Q.R. and Guo, S.W. (2014) Effects of Drought Stress on Photosynthesis and Water Status of Rice Leaves. Chinese Journal of Rice Science, 28, 65-70.

[32] Akram, H.M., Ali, A., Sattar, A., Rehman, H.S.U. and Bibi, A. (2013) Impact of Water Deficit Stress on Various Physiological and Agronomic Traits of Three Basmati Rice (Oryza sativa L.) Cultivars. Journal of Animal and Plant Sciences, 23, 1415-1423.

[33] Devaraju, K.M., Gowda, H. and Raju, B.M. (2012) Nitrogen Response of Karnataka Rice Hybrid 2. International Rice Research Notes, 23, 1.

[34] Karim, M.A. and Islam, M.T. (2001) Effect of Water Stress on Reproductive Stages in Transplanted Aman Rice. M.S. Thesis, Bangladesh Agricultural University, Mymensingh.

[35] Zubaer, M.A., Chowdhury, A.K.M.M.B., Islam, M.Z., Ahmed, T. and Hasan, M.A. (2007) Effects of Water Stress on Growth and Yield Attributes of Aman Rice Genotypes. International Journal of Sustainable Crop Production, 2, 25-30. 
[36] Kamoshita, A., Rodriguez, R., Yamauchi, A. and Wade, L. (2004) Genotypic Variation in Response of Rainfed Lowland Rice to Prolonged Drought and Rewatering. Plant Production Science, 7, 406-420. https://doi.org/10.1626/pps.7.406

[37] Rahman, M.A. and Ali, M.O. (2004) The Causes of Decreases in Pulse Production and Its Remeady. Krishi Biplop (A Fortnightly Magazine in Bengali), Rampura, Dhaka-1219, 5.

[38] Shahryari, R., Gurbanov, E., Gadimov, A. and Hassanpanah, D. (2008) Tolerance of 42 Bread Wheat Genotypes to Drought Stress after Anthesis. Pakistan Journal of Biological Sciences, 11, 1330-1335. http://dx.doi.org/10.3923/pjbs.2008.1330.1335

[39] Davatgar, N., Neishabouri, M.R., Sepaskhah, A.R. and Soltani, A. (2009) Physiological and Morphological Responses of Rice (Oryza sativa L.) to Varying Water Stress Management Strategies. International Journal of Plant Production, 3, 19-32.

[40] Zoinalabedin, T.S., Hemmatopah, P., Sanavy, S.A.M.M. and Babuchi, H. (2008) Study of Water Stress Effects in Different Growth Stages on Yield and Yield Components of Different Rice (Oryza saliva L.) Cultivars. Pakistan Journal of Biological Sciences, 11, 1303-1309. https://doi.org/10.3923/pjbs.2008.1303.1309

[41] Castillo, E.G., Tuong, T.P., Singh, U., Inubushi, K. and Padilla, J. (2006) Drought Response of Dry-Seeded Rice to Water Stress Timing and N-Fertilizer Rates and Sources. Soil Science and Plant Nutrition, 52, 496-508. http://dx.doi.org/10.1111/j.1747-0765.2006.00064.x

[42] Ji, K.X., Wang, Y.Y., Sun, W.N., Lou, Q.J., Mei, H.W., Shen, S.H. and Chen, H. (2012) Drought-Responsive Mechanisms in Rice Genotypes with Contrasting Drought Tolerance during Reproductive Stage. Journal of Plant Physiology, 169, 336-344. https://doi.org/10.1016/j.jplph.2011.10.010

[43] Maola, M.M. (2005) Effect of Gamma Radiation on Some Important Physiological and Yield Attributes in M2 Generation of Lentil. M.S. Thesis, Bangladesh Agricultural University, Mymensingh.

[44] Talukder, M.S. (2004) Effect of Gamma Rays on Large Seeded Rice. M.S. Thesis, Bangladesh Agricultural University, Mymensingh.

[45] O’Toole, J.C. and Moya, T.B. (1981) Water Deficits and Yield in Upland Rice. Field Crops Research, 4, 247-259. http://dx.doi.org/10.1016/0378-4290(81)90076-9

[46] Pantuwan, G., Fukai, S., Cooper, M., Rajatasereekul, S. and O’toole, J.C. (2002) Yield Response of Rice (Oryza sativa L.) Genotypes to Drought under Rainfed Lowlands: 2. Selection of Drought Resistant Genotypes. Field Crops Research, 73, 169-180. http://dx.doi.org/10.1016/S0378-4290(01)00195-2

[47] Acuña, T.B., Lafitte, H.R. and Wade, L.J. (2008) Genotyprie $\times$ Environment Interactions for Grain Yield of Upland Rice Backcross Lines in Diverse Hydrological Environments. Field Crops Research, 108, 117-125.

http://dx.doi.org/10.1016/j.fcr.2008.04.003

[48] Yang, J., Zhang, J., Wang, Z., Liu, L. and Zhu, Q. (2003) Postanthesis Water Deficits Enhance Grain Filling In Two-Line Hybrid Rice. Crop Science, 43, 2099-2108. https://doi.org/10.2135/cropsci2003.2099

[49] Farooq, M., Wahid, A. and Lee, D.J. (2009) Exogenously Applied Polyamines Increase Drought Tolerance of Rice by Improving Leaf Water Status, Photosynthesis and Membrane Properties. Acta Physiologiae Plantarum, 31, 937-945. http://dx.doi.org/10.1007/s11738-009-0307-2

[50] Anjum, S.A., Xie, X.Y., Wang, L.C., Saleem, M F., Man, C. and Lei, W. (2011) Morphological, Physiological and Biochemical Responses of Plants to Drought 
Stress. African Journal of Agricultural Research, 6, 2026-2032.

[51] Gana, A.S. (2011) Screening and Resistance of Traditional and Improved Cultivars of Rice to Drought Stress at Badeggi, Niger State, Nigeria. Agriculture and Biology Journal of North America, 2, 1027-1031. https://doi.org/10.5251/abjna.2011.2.6.1027.1031

[52] Bouman, B.A.M., Peng, S., Castaneda, A.R. and Visperas, R.M. (2005) Yield and Water Use of Irrigated Tropical Aerobic Rice Systems. Agricultural Water Management, 74, 87-105. http://dx.doi.org/10.1016/j.agwat.2004.11.007

[53] Ahadiyat, Y.R., Hidayat, P. and Susanto, U. (2014) Drought Tolerance, Phosphorus Efficiency and Yield Characters of Upland Rice Lines. Emirates Journal of Food and Agriculture, 26, 25-34. https://doi.org/10.9755/ejfa.v26i1.14417

[54] Guimarães, C.M., Stone, L.F., Rangel, P.H. and Silva, A.C.D.L. (2013) Tolerance of Upland Rice Genotypes to Water Deficit. Revista Brasileira de Engenharia Agrícola e Ambiental, 17, 805-810. http://dx.doi.org/10.1590/S1415-43662013000800001

[55] Araus, J.L., Villegas, D., Aparicio, N., Del Moral, L.F., El Hani, S., Rharrabti, Y., Ferrio, J.P. and Royo, C. (2003) Environmental Factors Determining Carbon Isotope Discrimination and Yield in Durum Wheat under Mediterranean Conditions. Crop Science, 43, 170-180. https://doi.org/10.2135/cropsci2003.1700

[56] Flexas, J., Bota, J., Loreto, F., Cornic, G. and Sharkey, T.D. (2004) Diffusive and Metabolic Limitations to Photosynthesis under Drought and Salinity in $\mathrm{C}_{3}$ Plants. Plant Biology, 6, 1-11. http://dx.doi.org/10.1055/s-2004-820867

[57] Rizza, F., Badeck, F.W., Cattivelli, L., Lidestri, O., Di Fonzo, N. and Stanca, A.M. (2004) Use of a Water Stress Index to Identify Barley Genotypes Adapted to Rainfed and Irrigated Conditions. Crop Science, 44, 2127-2137.

https://doi.org/10.2135/cropsci2004.2127

[58] Shashidhar, H.E., Pasha, F., Janamatti, M., Vinod, M.S. and Kanbar, A (2005) Correlation and Path Coefficient Analysis in Traditional Cultivars and Doubled Haploid Lines of Rainfed Lowland Rice (Oryza sativa L.). Oryza, 42, 156-159.

[59] Hounkpatin, A.S.Y. (2007) Sélection des génotypes de riz tolérants à la sécheresse (In French, with English Abstract). Mémoire d'Ingénieur des Travaux, Université d'Abomey-Calavi, Cotonou, Bénin.

[60] Ndjiondjop, M.N., Manneh, B., Cissoko, M., Drame, N.K., Kakai, R.G., Bocco, R., Baimey, H. and Wopereis, M. (2010) Drought Resistance in an Interspecific Backcross Population of Rice (Oryza spp.) Derived from the Cross WAB56-104 (O. sativa) $\times$ CG14 (O. glaberrima). Plant Science, 179, 364-373

http://dx.doi.org/10.1016/j.plantsci.2010.06.006

[61] Blum, A. (2000) Drought Tolerance-Is It a Complex Trait: In: Saxena, N.P. and O'Toole, J.C., Eds., Field Screening for Drought Tolerance in Crop Plants with Emphasis on Rice: Proceedings of an InternationalWorkshop on Field Screening for Drought Tolerance in Rice, 11-14 December 2000, ICRISAT, Patancheru, 11-14.

[62] Sharma, K.D., Pannu, R.K., Tyagi, P.K., Chaudhary, B.D. and Singh, D.P. (2003) Effect of Moisture Stress on Plant Water Relations and Yield of Different Wheat Genotypes. Indian Journal of Plant Physiology, 8, 99-102.

[63] Haque, S.S., Pradhan, K., Anandan, A., Dash, S.K., Swain, P. and Singh, O.N. (2014) Effectiveness of Traits for Direct Selection under Severe Drought Stress Condition in Rice. International Journal of Science and Technology, 2, 210-235.

[64] Chowdhury, M.J., Islam, M.T. and Islam, M.O. (2004) Evaluation of Two Local Transplant Aman Rice Cultivars and a Mutant under Soil Moisture Stress. Journal 
of the Bangladesh Society for Agricultural Science and Technology, 1, 127-131.

[65] Ratna, M., Begum, S., Husna, A., Dey, S.R. and Hossain, M.S. (2015) Correlation and Path Coefficients Analyses in Basmati Rice. Bangladesh Journal of Agricultural Research, 40, 153-161. http://dx.doi.org/10.3329/bjar.v40i1.23768

[66] Haque, M.A. and Haque, M.M. (2016) Growth, Yield and Nitrogen Use Efficiency of New Rice Variety under Variable Nitrogen Rates. American Journal of Plant Sciences, 7, 612-622. http://dx.doi.org/10.4236/ajps.2016.73054 